Medicine Updates

Faculty of medicine

‘October 2020,volume 3 https://muj.journals.ekb.eg

dean@med.psu.edu.eg

vice_dean_postgraduate@med.psu.edu.eg

DOI: 10.21608/muj.2020.40394.1018

ISSN : 2682-2741

Submitted: $24 / 8 / 2020$

Accepted : 26/8/2020

Pages:46-59

\title{
The role of microwave ablation in small and medium sized hepatocellular carcinoma treatment
}

Lamiaa Mobarak Assistant Professor, National hepatology and Tropical Medicine Research institute

Ahmed Farid Youssif Professor Diagnostic radiology department, faculty of medicine, Banha University

Hamada Khater Diagnostic radiology department, faculty of medicine, Banha University

Carmen Ali Zarad Diagnostic radiology faculty of medicine port said university

Zeinab Zakaria Assistant Professor Hepatogastroenterology and endemic medicine Dept, Kasr Al Ainy hospital, Faculty of Medicine, Cairo University, Egypt

Ahmed Shokry Adel Ministry of health

Wleed Elagawy Gastroenterology, Hepatology and Infectious diseases, faculty of medicine Port Said University

\begin{abstract}
Back ground and aim of work: Microwave ablation (MWA) is effective and safe technique used in treatment of hepatocellular carcinoma (HCC). The aim of this study is to investigate the role of microwave ablation in treatment of small and medium sized hepatocellular Carcinoma.
\end{abstract}


Methods: This prospective study included 50 patients who underwent microwave ablation for small and medium size hepatocellular carcinoma with abdominal ultrasound guidance. All patients' demographic, laboratory investigations and complications were recorded. To evaluate efficacy of microwave ablation, Contrast-enhanced computed tomography was done one month and repeated three months after the ablation.

Results: Complete ablation of the tumor was done in $92 \%$ of small HCC patients (less than or equal $3 \mathrm{~cm}$ ) whereas in 64\% among medium size $\mathrm{HCC}$ patients (more than 3 and up to 4 $\mathrm{cm})$. Tumor recurrence was recorded in one patient (4\%) with medium size HCC. There was significant decline in serum alpha fetoprotein levels one month after ablation compared to before the procedure. No major complications of the procedure or mortality were reported.

Conclusion: Microwave ablation is safe and effective in small to medium size HCC tumors treatment with no recorded major complications or mortality in addition to acceptable local tumor control.

\section{Keywords}

Hepatocellular carcinoma, Microwave ablation, small and medium sized lesions

\section{Introduction}

Hepatocellular carcinoma (HCC) is one of the most common primary liver neoplasms that proved to have poor prognosis worldwide. HCC has heterogeneity in manifestations, mutable biological behaviors, associated chronic liver diseases and different ways of therapy (Abdel Aziz et al, 2014). In Egypt, HCC is the second most common cancer in both sexes (ARC, 2012).

In patients with HCC combined with cirrhotic liver, only less than $30 \%$ are candidates for curative treatment at first diagnosis (He et al, 2010). In untreated patients the 3 -year survival rate ranges from $10 \%$ to $50 \%$ with moderate to advanced HCC (Bruix \& LIovet, 2002). Thermal ablation of HCC is effective, safe, and achieved long survival rates equal to those achieved by surgical resection of tumor (Abdel Aziz et al, 2014b).

Microwave ablation (MWA) is faster technique and can perform widely than radiofrequency ablation (RFA) for tumor up to five $\mathrm{cm}$ in size, tumor located around large hepatic blood 
vessels and tumors with high perfusion. Accordingly, it is considered as a curative treatment for large lesions (Shi et al, 2014), (Yu et al, 2008), (Brace, 2011).

MWA uses electromagnetic energy that produce homogenous and rapid heating of tumor tissue and so creating coagulation necrosis (Loukia, 2015).

In this study we aimed to investigate the role of microwave ablation in small (up to $3 \mathrm{~cm}$ ) and medium sized ( $>3 \mathrm{~cm}$ up to $4 \mathrm{~cm}$ ) $\mathrm{HCC}$.

\section{Patients and Methods:}

Patients:

We included 50 eligible patients in this prospective study. All patients diagnosed with cirrhosis and had either small or medium size up to $4 \mathrm{~cm}$ hepatocellular carcinoma recruited from outpatient clinics at faculty of medicine Banha University.

The diagnosis and managements of the studied patients followed the EASL, AASLD and BCLC guidelines for HCC management (Livet et al, 1999; Bruix et al, 2001 and Bruix \& Sherman, 2011). A written informed consent was obtained from all studied patients, and the study was in compliance with the ethics principles of the declaration of Helsinki.

According to the guidelines, all patients were Child Pugh A or B with solitary tumour $4 \mathrm{~cm}$ or less in diameter and a proper coagulation profile (prothrombin concentration $>60 \%$ and platelet count $>50.000 / \mathrm{mm}^{3}$ ). Exclusion criteria included patients with Child Pugh C, patients with portal vein thrombosis, distant metastases, neoplasm present near portal vein or inferior vena cava as they were technically difficult and neoplasms located within $1 \mathrm{~cm}$ of the liver hilum, gall bladder or common bile duct. Also tumours in the dome of the liver may be difficult to reach via percutaneously.

In this study patients were divided into two groups: the first group included 25 patients diagnosed with HCC less than or equal $3 \mathrm{~cm}$ and the second group included 25 patients diagnosed with $\mathrm{HCC}$ more than 3 and up to $4 \mathrm{~cm}$ in size. 
Before to the procedure, all studied patients were subjected to history taking, and complete physical examination,

many laboratory investigations were done for all patients like $\mathrm{CBC}$, Bilirubin level, total serum proteins level, AST, ALP ALT, albumin level, prothrombin time, prothrombin concentration, serum alpha fetoprotein level.

All patients subjected to radiological investigations include abdominal ultrasonography to evaluate the liver size, surface, echogenicity and HCC masses; also diameter of hepatic and portal veins was measured. Ultrasound examination of the spleen was done to evaluate its size, texture and presence of any focal lesions. Triphasic CT of the abdomen was done for all patients to confirm the diagnosis. Dynamic MRI was done for some patient with nonconclusive triphasic CT results. Fine Needle Aspiration Cytology (FNAC) or Tru-cut biopsy was taken from focal hepatic lesion if the results of triphasic CT and dynamic contrast enhanced MRI were non-conclusive.

Follow-up of all patients was done 1 month and 3 months after the MWA session. Laboratory investigations also repeated after MWA session like Bilirubin level, AST, ALT, alkaline phosphatase, and albumin level. Abdominal ultrasonography done after the procedure to assess the focal lesion size, echogenicity, color Doppler behavior, presence of any recurrence, portal vein thrombosis, development of any complication like hematoma or abscess formation and development of ascites.

Triphasic CT was done 1 month after the end of MWA sessions to evaluate the presence of any remaining viable tumor tissue. The remaining hepatic tumor viability was better evaluated during the early arterial phase of the contrast-enhanced triphasic CT imaging that imaged 6 and 35second after the intravenous contrast infusion and at the late phase of the triphasic CT imaging that imaged 90 second after the intravenous contrast infusion. According to triphasic CT results the response to MWA treatment was rated as complete response when triphasic CT scans showed no any contrast enhancement inside the hepatic tumors in the arterial phase. The response to MWA was rated as partial response when 
triphasic CT scans showed enhancements areas within the hepatic lesion boundaries in the arterial phase.

We used dynamic MRI for follow up the response of MWA if the hepatic lesion was initially diagnosed by dynamic MRI.

Methods:

MWA was done with conscious patient under conscious analgesia and sedation that induced by administration of intravenous propofol (Deprivan) by dose 3 to $6 \mathrm{mg} / \mathrm{kg}$ body weight. All the patients underwent percutaneous MWA under real-time abdominal ultrasound with a 3.55.0 MHz curved probe (EUB-5500, Hitachi, Tokyo, Japan)

A freehand technique was done by using HS AMICA microwave machine (HS Hospital Service, Rome, Italy) with a power up to $100 \mathrm{~W}$ for 10-20 minute and frequency of 2450 MHz. A cooled shift electrodes 14-gauge or $150 \mathrm{~mm}$ (AMICA probes, HS Hospital Service) were used to generate microwave energy into the hepatic tissue.

\section{Statistical analysis:}

We reported numerical data like means \pm standard deviation (S.D). Also all categorical data were represented as counts and percentages. We used the student t-test and the Chi-square test when appropriate. $\mathrm{P}$ value more than 0.05 was considered as statistically non-significant while $\mathrm{P}$ value less than or equal 0.05 was considered as statistically significant. $\mathrm{P}$ value less than or equal 0.001 was considered as statistically highly significant.

\section{Results}

This study included 50 patients. The 50 patients divided into two groups according to the size of hepatic focal lesions; the first group included 25 patients with HCC less than or equal 3 $\mathrm{cm}$ and the second group 2 included 25 patients with $\mathrm{HCC}$ more than $3 \mathrm{~cm}$ up to $4 \mathrm{~cm}$. Male predominance was seen in both groups $(76 \%)$ in group $1 \&(56 \%)$ in group 2 . Most patients were infected with hepatitis $\mathrm{C}$ virus $(\mathrm{n}=24,96 \%)$ in group 1 and $(\mathrm{n}=23,92 \%)$ in group2. Most patients were Child-Pugh B $(n=18,72 \%)$ in group 1 and $(n=19,76 \%)$ in group 2. Hepatomegaly was recorded in $8 \%(2 / 25)$ in each group. Table (1) 
Before the procedure abdominal ultrasound findings of the patients showed that most of hepatic focal lesions were present in the right hepatic lobe mainly segment VII $(10 / 25 ; 40 \%$ of patients) in group 1 while in group 2 segment VI (7/25; $28 \%$ of patients) followed by segment V $(6 / 25 ; 24 \%$ of patients). The hepatic lesions were most commonly hypoechoic (88\% of patients) in each group. Table (2)

As shown in table 3, serum levels of ALT and AFP were significantly decreased one month after MWA compared with those before the procedure ( $\mathrm{P}=.02 \& 0.01$ respectively).

As regard group2, Serum levels of albumin were significantly increased and that of AFP were significantly decreased one month after MWA compared with those before the procedure $(\mathrm{P}=0.01 \& 0.004$ respectively). Table (4)

One month after MWA abdominal triphasic CT showed that complete and successful ablation of the hepatic lesions in 23/25 (92\%) among the first group whereas in 16/25 (64\%) among the second group. Eleven patients with partial ablation were subjected to a second session of MWA. Triphasic CT was performed in all patients 3 months after the ablation showing complete ablation in patients with HCC less than or equal $3 \mathrm{~cm}$ whereas one recurrence case (4\%) in patients with $\mathrm{HCC}$ more than $3 \mathrm{~cm}$ and up to $4 \mathrm{~cm}$ who previously well ablated with no further treatment. Denovo lesion was recorded in one patients (4\%) one month after MWA among group with HCC (>3 up to $4 \mathrm{~cm}$ ) which did not meet the criteria for treatment. Table (5)

No procedure related major complications or mortality were observed in our patients. Minor complications including right hypochondrial pain was recorded (4\%) and (12\%) in group 1 and group 2 respectively. The pain was improved after symptomatic treatment which was prescribed routinely. Table (6)

\section{Discussion}

Microwave ablation is a comparatively new technique that presents more advantages over RFA as well as can be applied to several types of tumors. MWA showed a considerable cellular necrosis with better heating of the lesion offering reduction in the time needed for ablation, applying many antennae simultaneously, efficacy on cystic lesions and/or lesions near to vascular structures more than $3 \mathrm{~mm}$ in diameter with a decrease in the heating effect, 
and minimal procedure related pain (IARC, 2012). Hopeful results of MWA for HCC have been reported in various studies (Wang et al, 2008).

The aim of this study was to evaluate the role of microwave ablation in small (up to $3 \mathrm{~cm}$ ) and medium sized $\mathrm{HCC}$ (>3 $\mathrm{cm}$ up to $4 \mathrm{~cm}$ ). Aaccording to the size of the hepatic focal lesions; we divided the studied patients into two groups: group one that included 25 patients with small size HCC $(\leq 3 \mathrm{~cm})$ and group two that included 25 patients with midum sized $\mathrm{HCC}(>3$ up to $4 \mathrm{~cm})$.

The mean age of the patients included in the study was in consistent with Chen et al., 2002 who mentioned that $\mathrm{HCC}$ incidence was significantly higher among advancing age. The male to female ratio in our study groups ranged from 2:1 to 8:1 in the first and second groups respectively (Livet et al, 2003) (Tangkijvanich et al, 2004). Similarly in the present study a male predominance was reported $(76 \% \& 56 \%)$ in patients with $\mathrm{HCC}$ less than or equal and those with 3 to $4 \mathrm{~cm} \mathrm{HCC}$ respectively.

Most of our patients infected with HCV (96\%) in group one and (92\%) in group two. The same finding was observed by Bugianesi et.al. (Bugianesi et.al. 2007).

Most of the studied patients were at Child -Pugh A classification, which was similar to that reported in the study of Medhat et. al. (Medhat et al, 2015).

MWA is as effective as surgical resection for solitary HCC $\leq 3 \mathrm{~cm}$ (Shi et al, 2014). In the present study, the complete ablation rates for hepatic tumors less than or equal $3 \mathrm{~cm}$ and those hepatic tumors larger than 3 to $4 \mathrm{~cm}$ were $(23 / 25 ; 92 \%)$ and $(16 / 25 ; 64 \%)$ respectively. These results were quite lower than results reported by $\mathrm{Lu}$ et al. who recorded ablation rates of hepatic tumors smaller than or equal $2 \mathrm{~cm}$ and hepatic tumors larger than $2 \mathrm{~cm}$ were $98 \%$ and 92\%, respectively (Lu et al. 2001). In this study, the eleven incompletely ablated hepatic lesions were treated with additional sessions of microwave ablation. Also Lu et al. (2001) achieved complete ablation in all incompletely ablated tumors. Our study results were relatively lower than results reported by Kung et al. (2007) they reported that the complete ablation rates of hepatic lesions were $94 \%, 91 \%$, and $92 \%$ for small lesions less than or equal $3 \mathrm{~cm}$, intermediate ranging from 3.1 to $5.0 \mathrm{~cm}$ and large ranging from 5.1 to $8.0 \mathrm{~cm}$ liver cancers. 
In addition to Xu et al. (2004) who found the complete ablation rates one month after MWA in tumors size $2.0,2.1$ to 3.9 and $4.0 \mathrm{~cm}$ in diameter were $93.1 \%, 93.8 \%$, and $86.4 \%$ respectively.

In our study, there was a significant decline in serum AFP level $(\mathrm{P}=)$, this was explained by successful MW ablation, and these was similar to Lu et al. (2001) and Dong et al (2003) results.

Abdelaziz et al (2014b) in a recent study, determined the safety of MWA for early-stage HCC lesions. In a multicenter study, Livraghi et al (2012) stated the safety of MWA as reported $0 \%$ mortality, $7.2 \%$ minor complications and $2.9 \%$ major complications. These results were comparative with ours results as no major complications related to the MWA procedure or mortality was observed in our study. Minor complications including right hypochondrial pain was recorded (4\%) and (12\%) in group 1 and group 2 respectively. The pain was improved after routine symptomatic treatment. The study of Lu et al. (2001), concluded that the one year survival rate was $96 \%$, and that Dong et al. (2003), concluded that the one year survival rate was $92.7 \%$.

This study was a short term study focused on efficacy and safety of MWA rather than a long term follow up. Further studies are needed for long term follow up and survival rate study.

In conclusion: Percutaneous microwave ablation is safe and effective procedure used in the treatment of small to medium size up to $4 \mathrm{~cm} \mathrm{HCC}$ tumors as no major complications were recorded and acceptable local tumor control.

Abbreviation

MWA: Microwave ablation

HCC: hepatocellular carcinoma.

AFP: alpha fetoprotein

EASL: European Association for the Study of the Liver.

AASLD: American Association for the Study of Liver Diseases. 
BCLC: Barcelona clinic liver cancer

AST: aspartate aminotransferase

ALP: Alkaline phosphatase .

ALT: Alanine aminotransferase.

CT: Computed Tomography.

MRI: Magnetic Resonance Imaging.

\section{References}

- Abdelaziz A, Elbaz T, Shousha HI et al. Efficacy and survival analysis of percutaneous radiofrequency versus microwave ablation for hepatocellular carcinoma: an Egyptian multidisciplinary clinic experience. SurgEndosc 2014; 28:3429-34.

- Abdelaziz AO, Elbaz TM, Shousha HI et al. Survival andprognostic factors for hepatocellular carcinoma: an Egyptian multidisciplinary clinic experience. Asian Pac J Cancer Prev 2014; 15: 3915-20.

- Brace CL. Dual-slot antennas for microwave tissue heating:parametric design analysis and experimental validation. Med Phys 2011; 38: 4232-40.

- Brace CL. Radiofrequency and microwave ablation of the liver,lung, kidney, and bone: what are the differences? Curr Probl Diagn Radiol 2009; 38: 135-143 [PMID: 19298912 DOI: 10.1067/j.cpradiol.2007.10.001].

- Bruix J, Llovet JM. Prognostic prediction and treatment strategy in hepatocellular carcinoma. Hepatology 2002; 35:519-24.

- Bruix J, Sherman M, Llovet JM. EASL Panel of Experts on HCC. Clinical management of hepatocellular carcinoma. Conclusions of the Barcelona-2000 EASL conference. European Association for the Study of the Liver J Hepatol. 35(3):421-430.

- Bruix J, Sherman M. American Association for the Study of Liver Diseases. Management of hepatocellular carcinoma: an update. Hepatology 2011. 53(3):1020-1022.

- Bugianesi E. The incidence of HCV-related HCC has also increased in recent years. Nonalcoholic steatohepatitis and cancer Clin Liver Dis. 2007, 11, pp. 191-207. 
- Carrafiello G, Laganà D, Mangini M, et al. Microwave tumors ablation: principles, clinical applications and review of preliminary experiences. Int J Surg. 2008;1:S65-S69.

- Chen TH, Chen CJ, Yen MF, et al. Ultrasound screening and risk factors for death from hepatocellular carcinoma in a high risk group in

- Dong B, Liang P, Yu E, et al.Percutaneous sonographically guided microwave coagulation therapy for hepatocelluar carcinoma: results in 234 patients AJR 2003; 180 , pp. 1547-1555.

- He AR, Soe K, El Zouhairi M et al. Current problems with systemic treatment of advanced hepatocellular carcinoma.CurrProbl Cancer 2010; 34: 131-49.

- International Agency for Research on Cancer (IARC).GLOBOCAN. Estimated cancer incidence, mortality and prevalence worldwide in 2012. Available online:http://globocan.iarc.fr.

- Kuang M, Lu MD, Xie XY, et al. Liver cancer: increased microwave delivery to ablation zone with cooled-shaft antenna - experimental and clinical studies Radiology 2007; 242 , pp. 914-924.

- Livraghi T, Meloni F, Solbiati L, et al. Collaborative Italian Group using AMICA system. Complications of microwave ablation for liver tumors: results of a multicenter study. Cardiovasc Intervent Radiol. 2012; 35:868-874.

- Llovet JM, Bustamante J, Castells A, Vilana R, Ayuso Mdel C, Sala M, Brú C, Rodés J, Bruix J (1999) Natural history of untreated nonsurgical hepatocellular carcinoma: rationale for the design and evaluation of therapeutic trials. Hepatology; 29(1):62-67.

- Llovet JM, Burroughs A, Bruix J. Hepatocellular carcinoma Lancet 2003; 362, pp. 19071917.

- Loukia S Poulou. " Percutaneous microwave ablation radiofrequency ablation in the treatment of hepatocellular carcinoma ", World Journal of Hepatology, 2015

- Lu MD, Chen JW, Xie XY, et al. Hepatocellular carcinoma Sonography-guided percuteneous micro-wave coagulation therapy. Radiology 2001; 221, pp. 167-172. 
- Medhat E, Abdel Aziz A, Zakaria Z, et al. Value of Microwave Ablation in Treatment of large lesions of Hepatocellular Carcinoma. JDD 2015; 16(8): 456-463.

- Poggi G, Montagna B, Di Cesare P et al. Microwave ablation of hepatocellular carcinoma using a new percutaneous device: preliminary results. Anticancer Res 2013; 33: 1221-7.

- Shi J, Sun Q, Wang Y, et al. Comparison of microwave ablation and surgical resection for treatment of hepatocellular carcinomas conforming to Milan criteria. J Gastroenterol Hepatol. 2014;29:1500-1507.

- Taiwan Int J Cancer 2002; 98, pp. 257-261

- Tangkijvanich $\mathrm{P}$, Mahachai $\mathrm{V}$, Suwangool $\mathrm{P}$, et al. Gender difference in clinicopathologic features and survival of patients with hepatocellular carcinoma World $\mathbf{J}$ Gastroenterol 2004; 10 , pp. 1547-1550.

- Wang ZL, Liang P, Dong BW, et al. Prognostic factors and recurrence of small hepatocellular carcinoma after hepatic resection or microwave ablation: a retrospective study. J Gastrointest Surg. 2008; 2:327-337.

- Xu HX, Xie XY, Lu MD et al.Ultrasound-guided percutaneous thermal ablation of hepatocellular carcinoma using microwave and radio-frequency ablation Clin Radiol 2004; 59 , pp. 53-61.

- Yu NC, Raman SS, Kim YJ, Lassman C, Chang X, Lu DS. Microwave liver ablation: influence of hepatic vein size on heat-sink effect in a porcine model. J VascIntervRadiol 2008; 19: 1087-92. 
Table (1): General characteristics and baseline laboratory data of the studied HCC groups

\begin{tabular}{|c|c|c|}
\hline & $\begin{array}{l}\text { HCC patients } \\
\text { Group } 1(\mathrm{n}=25) \\
\text { (Mean } \pm \text { S.D.) }\end{array}$ & $\begin{array}{l}\text { HCC patients } \\
\text { Group } 2(n=25) \\
\text { (Mean } \pm \text { S.D. })\end{array}$ \\
\hline \multirow[t]{2}{*}{ Age } & $60.48 \pm 7.78$ & $56.72 \pm 9.33$ \\
\hline & $\mathbf{N}(\%)$ & $\mathbf{N}(\%)$ \\
\hline $\begin{array}{l}\text { Sex } \\
\text { Male } \\
\text { Female }\end{array}$ & $\begin{array}{c}19(76) \\
6(24)\end{array}$ & $\begin{array}{l}14(56) \\
11(44)\end{array}$ \\
\hline $\begin{array}{l}\text { Child-Pugh } \\
\text { Child A } \\
\text { Child B }\end{array}$ & $\begin{array}{c}21 / 25(84 \%) \\
4 / 25(16 \%)\end{array}$ & $\begin{array}{c}23 / 25(92 \%) \\
2 / 25(8 \%)\end{array}$ \\
\hline $\begin{array}{l}\text { Comorbitity } \\
\text { No } \\
\text { Yes }\end{array}$ & $\begin{array}{l}18 / 25(72 \%) \\
7 / 25(28 \%)\end{array}$ & $\begin{array}{c}19 / 25(76 \%) \\
6 / 25(24 \%)\end{array}$ \\
\hline Yes & $($ Mean \pm S.D. $)$ & $($ Mean \pm S.D. $)$ \\
\hline Hb $(12-17$ gm/dl $)$ & $11.79 \pm 0.87$ & $11.92 \pm 0.84$ \\
\hline WBC $\left(4-10 \times 10^{3} / \mathrm{mm}^{3}\right)$ & $3488.0 \pm 529.40$ & $3752.0 \pm 473.56$ \\
\hline 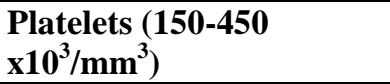 & $144.84 \pm 60.89$ & $154.12 \pm 68.25$ \\
\hline $\begin{array}{l}\text { Total bilirubin (0.1-1.2 } \\
\mathrm{mg} / \mathrm{dl})\end{array}$ & $1.63 \pm 0.35$ & $1.56 \pm 0.29$ \\
\hline ALT (up to 42 IU/L) & $51.84 \pm 19.89$ & $49.16 \pm 19.56$ \\
\hline AST (up to 42 IU/L) & $49.16 \pm 19.85$ & $47.32 \pm 19.26$ \\
\hline Albumin (3.5-5.5gm/dl) & $3.64 \pm 0.39$ & $1.56 \pm 0.29$ \\
\hline INR & $1.22 \pm 0.10$ & $1.21 \pm 0.08$ \\
\hline PC & $76.56 \pm 13.48$ & $79.20 \pm 13.70$ \\
\hline Alpha fetoprotein (ng/ml) & $59.80 \pm 63.78$ & $42.90 \pm 55.08$ \\
\hline Creatinine & $1.0 \pm 0.26$ & $1.16 \pm 0.18$ \\
\hline $\mathrm{HCV} / \mathrm{HBV}$ & $24 / 1(96 \% / 4.0 \%)$ & $23 / 2(92 \% / 8.0 \%)$ \\
\hline
\end{tabular}

Table (2): Ultrasonographic features of the studied patients

Before MWA:

\begin{tabular}{|c|c|c|}
\hline & $\begin{array}{c}\text { HCC patients } \\
\text { Group } 1(\mathrm{n}=25) \\
\mathbf{N}(\%) \\
\end{array}$ & $\begin{array}{c}\text { HCC patients } \\
\text { Group } 2(n=25) \\
\text { N }(\%)\end{array}$ \\
\hline $\begin{array}{l}\text { Liver size } \\
\text { Average } \\
\text { Enlarged } \\
\text { Shrunken }\end{array}$ & $\begin{array}{l}21(84) \\
2(8) \\
2(8)\end{array}$ & $\begin{array}{c}23(92) \\
2(8) \\
0\end{array}$ \\
\hline $\begin{array}{c}\text { Segment number } \\
1 \\
2 \\
3 \\
4 \\
5 \\
6 \\
7 \\
8\end{array}$ & $\begin{array}{c}0 \\
0 \\
2(8) \\
0 \\
7(28) \\
3(12) \\
10(40) \\
3(12)\end{array}$ & $\begin{array}{c}1(4) \\
3(12) \\
2(8) \\
1(4) \\
6(24) \\
7(28) \\
3(12) \\
2(8) \\
\end{array}$ \\
\hline $\begin{array}{l}\text { Lesion echogenecity } \\
\text { Hypoechoic } \\
\text { heterogenous }\end{array}$ & $\begin{array}{c}22(88) \\
3(12)\end{array}$ & $\begin{array}{c}22(88) \\
3(12)\end{array}$ \\
\hline $\begin{array}{l}\text { Size of lesion mean } \pm \\
\text { SD }\end{array}$ & $2.39 \pm 0.35$ & $3.60 \pm 0.35$ \\
\hline
\end{tabular}


Table (3): Baseline and follow up laboratory data one month after microwave ablation in group 1

\begin{tabular}{|c|c|c|c|}
\hline & $\begin{array}{c}\text { Before ablation } \\
\text { (Mean } \pm \text { S.D. })\end{array}$ & $\begin{array}{l}\text { After ablation } \\
(\text { Mean } \pm \text { S.D. })\end{array}$ & $P$ value \\
\hline Hb $(12-17$ gm/dl $)$ & $11.79 \pm 0.87$ & $11.34 \pm 0.82$ & 0.07 \\
\hline WBC $\left(4-10 \times 10^{3} / \mathrm{mm}^{3}\right)$ & $3488.0 \pm 529.40$ & $3480.0 \pm 435.89$ & 0.95 \\
\hline 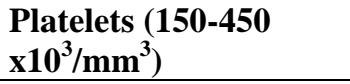 & $144.84 \pm 60.89$ & $115.04 \pm 49.20$ & 0.08 \\
\hline $\begin{array}{l}\text { Total bilirubin (0.1- } \\
1.2 \mathrm{mg} / \mathrm{dl})\end{array}$ & $1.63 \pm 0.35$ & $1.54 \pm 0.34$ & 0.38 \\
\hline ALT (up to 42 IU/L) & $51.84 \pm 19.89$ & $40.44 \pm 8.43$ & 0.02 \\
\hline AST (up to 42 IU/L) & $49.16 \pm 19.85$ & $41.64 \pm 9.07$ & 0.12 \\
\hline $\begin{array}{l}\text { Albumin }(3.5- \\
5.5 \mathrm{gm} / \mathrm{dl})\end{array}$ & $3.64 \pm 0.39$ & $3.37 \pm 0.39$ & 0.01 \\
\hline INR & $1.22 \pm 0.10$ & $1.27 \pm 0.11$ & 0.14 \\
\hline PC & $76.56 \pm 13.48$ & $75.24 \pm 9.90$ & 0.70 \\
\hline $\begin{array}{l}\text { Alpha fetoprotein } \\
\text { (ng/ml) }\end{array}$ & $59.80 \pm 63.78$ & $28.80 \pm 27.59$ & 0.01 \\
\hline
\end{tabular}

Table (4): Baseline and follow up laboratory data one month after microwave ablation in group 2

\begin{tabular}{|c|c|c|c|}
\hline & $\begin{array}{c}\text { Before ablation } \\
\text { (Mean } \pm \text { S.D.) }\end{array}$ & $\begin{array}{l}\text { After ablation } \\
(\text { Mean } \pm \text { S.D. })\end{array}$ & $P$ value \\
\hline Hb (12-17 gm/dl) & $11.92 \pm 0.84$ & $11.36 \pm 0.57$ & 0.000 \\
\hline WBC $\left(4-10 \times 10^{3} / \mathrm{mm}^{3}\right)$ & $3752.0 \pm 473.56$ & $3888.0 \pm 378.94$ & 0.21 \\
\hline $\begin{array}{l}\text { Platelets (150-450 } \\
\left.\times 10^{3} / \mathrm{mm}^{3}\right)\end{array}$ & $154.12 \pm 68.25$ & $139.60 \pm 54.98$ & 0.11 \\
\hline $\begin{array}{l}\text { Total bilirubin (0.1- } \\
1.2 \mathrm{mg} / \mathrm{dl})\end{array}$ & $1.56 \pm 0.29$ & $1.49 \pm 0.38$ & 0.28 \\
\hline ALT (up to 42 IU/L) & $49.16 \pm 19.56$ & $44.28 \pm 13.47$ & 0.28 \\
\hline AST (up to 42 IU/L) & $47.32 \pm 19.26$ & $46.40 \pm 17.08$ & 0.82 \\
\hline $\begin{array}{l}\text { Albumin }(3.5- \\
5.5 \mathrm{gm} / \mathrm{dl})\end{array}$ & $1.56 \pm 0.29$ & $3.45 \pm 0.38$ & 0.01 \\
\hline INR & $1.21 \pm 0.08$ & $1.25 \pm 0.97$ & 0.03 \\
\hline PC & $79.20 \pm 13.70$ & $76.44 \pm 11.53$ & 0.39 \\
\hline $\begin{array}{l}\text { Alpha fetoprotein } \\
(\mathrm{ng} / \mathrm{ml})\end{array}$ & $42.90 \pm 55.08$ & $20.01 \pm 20.93$ & 0.004 \\
\hline
\end{tabular}

Table (5): Success rate of MWA

\begin{tabular}{|c|c|c|c|c|c|}
\hline \multicolumn{2}{|r|}{ Item } & \multirow{2}{*}{$\begin{array}{c}\text { HCC patients } \\
\text { Group 1 } \\
\mathbf{N}=\mathbf{2 5}\end{array}$} & \multirow{2}{*}{$\begin{array}{c}\text { HCC patients } \\
\begin{array}{c}\text { Group } 2 \\
\mathbf{N}=25\end{array} \\
16(64 \%)\end{array}$} & \multirow{2}{*}{$\begin{array}{c}\text { Total } \\
39(78 \%)\end{array}$} & \multirow{3}{*}{ P value } \\
\hline \multirow[t]{2}{*}{ After one month } & Complete ablation & & & & \\
\hline & Partial ablation & $2(8 \%)$ & $9(36 \%)$ & $11(22 \%)$ & \\
\hline \multirow[t]{2}{*}{$\begin{array}{l}\text { After three } \\
\text { months }\end{array}$} & Still Complete ablation & $25(100 \%)$ & $24(96 \%)$ & 49 & \multirow[t]{2}{*}{1.0} \\
\hline & Recurrence & $0(0 \%)$ & $1(4 \%)$ & 1 & \\
\hline
\end{tabular}


Table (6): Follow up data of the studied patient

\begin{tabular}{|c|c|c|}
\hline & $\begin{array}{l}\text { HCC patients } \\
\text { Group } 1(\mathrm{n}=25) \\
\end{array}$ & $\begin{array}{l}\text { HCC patients } \\
\text { Group } 2(\mathrm{n}=25)\end{array}$ \\
\hline & $\begin{array}{c}\text { One month and three months } \\
\text { post MWA }\end{array}$ & $\begin{array}{c}\text { One month and three months } \\
\text { post MWA }\end{array}$ \\
\hline Distant metastasis & 0 & 0 \\
\hline P.V. thrombosis & 0 & 0 \\
\hline $\begin{array}{l}\text { Major Complications } \\
\text { Pleural effusion, subcapsular } \\
\text { hematoma, thigh burns }\end{array}$ & 0 & 0 \\
\hline Minor Complications: & 0 & 0 \\
\hline Pain & $1(4 \%)$ & $3(12 \%)$ \\
\hline Fever & 0 & 0 \\
\hline Decompensation : mild ascites & $1(4 \%)$ & $1(4 \%)$ \\
\hline Mortality & 0 & 0 \\
\hline
\end{tabular}

